\title{
PEMIKIRAN FILSAFAT HUKUM KE ARAH KEPRIBADIAN BANGSA
}

\author{
Oleh: \\ RONY ANDRE CRISTIAN NALDO, SH, MH \\ MESTIANA PURBA, SH, MH \\ Dosen Universitas Simalungun \\ Email: ronyandre87@,gmail.com, \\ mestianapurba@gmail.com
}

\begin{abstract}
ABSTRAK
Kehadiran filsafat hukum memiliki arti dan peran besar bagi eksistensi dan pengembangan ilmu-ilmu pengetahuan hukum termasuk ilmu hukum dalam masa-masa dulu hingga sekarang di berbagai negara. Demikian pula halnya di Indonesia. Hal ini adalah lumrah adanya karena filsafat pada umumnya merupakan induk pokok dari semua ilmu pengetahuan yang ada dan dikenal umat manusia hingga saat ini. Ketika ilmu pengetahuan hukum berakhir karena tidak mampu memberi jawaban yang memuaskan, maka pada saat itulah filsafat tampil sebagai dewa penolong. Hal ini terutama karena filsafat hukum juga mempelajari pertanyaan-pertanyaan yang tidak terjawab oleh ilmu hukum. Kehadiran filsafat hukum memiliki arti dan peran besar bagi eksistensi dan pengembangan ilmu-ilmu pengetahuan hukum termasuk ilmu hukum dalam masa-masa dulu hingga sekarang di berbagai negara. Demikian pula halnya di Indonesia. Indonesia merupakan negara hukum (recht staat), dan bukan merupakan negara kekuasaan (macht staat). Hal tersebut ditegaskan berdasarkan ketentuan Pasal 1 ayat (3) Undang-Undang Dasar Negara Republik Indonesia Tahun 1945 (UUD 1945), yang menentukan bahwa: Negara Indonesia adalah negara hukum. Indonesia memiliki kepribadian bangsa. Kepribadian dapat diartikan sebagai sifat hakiki yang tercermin pada sikap seseorang atau suatu bangsa yang membedakannya dari orang atau bangsa lain. Bangsa dapat diartikan sebagai masyarakat yang bersamaan asal keturunan, adat, bahasa, dan sejarahnya, serta berpemerintahan sendiri. Berdasarkan pemaparan mengenai arti kepribadian dan arti bangsa, dapat ditegaskan bahwa kepribadian bangsa adalah ciri-ciri watak menonjol yang ada pada banyak warga suatu kesatuan nasional. Maka filsafat kepribadian bangsa seharusnya sudah kembali kepada eksistensinya dalam realita kehidupan bangsa dalam menjadikan sumber dari segala sumber hukum.
\end{abstract}

Kata Kunci: Pemikiran, Filsafat Hukum, Kpribadian, Bangsa.

\section{PENDAHULUAN}

\subsection{Latar Belakang Masalah}

Perkembangan

Ilmu

Pengetahuan dan Teknologi (IPTEK)

telah begitu pesat. Dengan ilmu yang

dimiliki manusia, sudah banyak

masalah yang berhasil dipecahkan.

Sebanyak dan semaju apapun ilmu

yang dimiliki manusia tetap saja ada

berbagai pertanyaan yang belum bisa

dijawab. Maka ketika ilmu tidak lagi mampu menjawab, berbagai pertanyaan tersebut menjadi porsi pekerjaan filsafat.

Berfilsafat adalah berpikir. Hal ini tidak berarti setiap berpikir adalah berfilsafat, karena berfilsafat itu berpikir dengan ciri-ciri tertentu. Teguh Prasetyo, dan Abdul Halim Barkatullah, menentukan bahwa:

"Ada beberapa ciri berpikir secara kefilsafatan, yaitu: 
1. Berpikir secara kefilsafatan dicirikan secara radikal. Radikal berasal dari kata Yunani, radix yang berarti akar. Berpikir secara radikal adalah berpikir sampai ke akarakarnya. Berpikir sampai ke hakikat, esensi, atau sampai ke substansi yang dipikirkan. Manusia yang berfilsafat tidak puas hanya memperoleh pengetahuan lewat indera yang selalu berubah dan tidak tetap. Manusia yang berfilsafat dengan akalnya berusaha untuk dapat menangkap pengetahuan hakiki, yaitu pengetahuan yang mendasari segala pengetahuan inderawi;

2. Berpikir secara kefilsafatan dicirikan secara universal (umum). Berpikir secara universal adalah berpikir tentang hal-hal serta prosesproses yang bersifat umum. Filsafat bersangkutan dengan pengalaman umum dari umat manusia (common experience of mankind). Dengan jalan penjajakan yang radikal, filsafat berusaha untuk sampai pada kesimpulan-kesimpulan yang universal. Bagaimana cara atau jalan yang ditempuh untuk mencapai sasaran pemikirannya dapat berbeda-beda. Akan tetapi yang dituju adalah keumuman yang diperoleh dan hal-hal khusus yang ada dalam kenyataan;
3. Berpikir secara kefilsafatan dicirikan secara konseptual. Yang dimaksud dengan konsep disini adalah hasil generalisasi dan abstraksi dan pengalaman tentang hal-hal serta proses-proses individual. Berfilsafat tidak berpikir tentang manusia tertentu atau manusia khusus, tetapi berpikir tentang manusia secara umum. Dengan ciri yang konseptual ini, berpikir secara kefilsafatan melampaui batas pengalaman hidup sehari-hari;

4. Berpikir secara kefilsafatan dicirikan secara koheren dan konsisten. Koheren artinya sesuai dengan kaidah-kaidah berpikir (logis). Konsisten artinya tidak mengandung kontradiksi. Baik koheren maupun konsisten, keduanya dapat diterjemahkan dalam bahasa Indonesia yakni runtut. Adapun yang dimaksud runtut adalah bagan konseptual yang disusun tidak terdiri atas pendapatpendapat yang saling berkontradiksi didalamnya;

5. Berpikir secara kefilsafatan dicirikan secara sistematik. Sistematik berasal dari kata sistem yang artinya kebulatan dari sejumlah unsur yang saling berhubungan menurut tata pengaturan untuk mencapai sesuatu 
maksud atau menunaikan sesuatu

peranan tertentu. Dalam

mengemukakan jawaban terhadap

suatu masalah, digunakan pendapat

atau argument yang merupakan

uraian kefilsafatan yang saling

berhubungan secara teratur dan

terkandung adanya maksud atau

tujuan tertentu;

6. Berpikir secara kefilsafatan dicirikan secara komprehensif.

Komprehensif adalah mencakup secara menyeluruh. Berpikir secara kefilsafatan berusaha untuk menjelaskan fenomena yang ada di alam semesta secara keseluruhan sebagai suatu sistem;

7. Berpikir secara kefilsafatan dicirikan secara bebas. Sampai batas-batas yang luas, setiap filsafat boleh dikatakan merupakan suatu hasil dari pemikiran yang bebas. Bebas dari prasangka-prasangka sosial, historis, kultural, atau religius. Sikap-sikap bebas demikian ini banyak dilukiskan oleh filsuf-filsuf dari segala zaman. Socrates memilih meminum racun dan menatap maut dari pada harus mengorbankan kebebasannya untuk berpikir menurut keyakinannya. Spinoza karena khawatir kehilangan kebebasannya untuk berpikir, menolak pengangkatannya sebagai guru besar filsafat pada Universitas Heidelberg;

8. Berpikir secara kefilsafatan dicirikan dengan pemikiran yang bertanggung jawab. Pertanggungjawaban yang pertama adalah terhadap hati nuraninya. Disini tampak hubungan antara kebebasan berpikir dalam filsafat dengan etika yang melandasinya". ${ }^{1}$

Sebagaimana berpikir secara kefilsafatan, maka pemikiran filsafat hukum juga memiliki beberapa sifat atau karateristik khusus yang membedakannya dengan ilmu-ilmu lainnya, sebagai berikut:

1. Bersifat menyeluruh dan universal. Dengan cara berpikir holistik tersebut, maka siapa saja yang mempelajari filsafat hukum diajak untuk berwawasan luas dan terbuka. Mereka diajak untuk menghargai pemikiran, pendapat, dan pendirian orang lain. Itulah sebabnya dalam filsafat hukum pun dikenal pula berbagai aliran pemikiran tentang hukum, dengan segala kelebihan dan kekurangannya. Dengan demikian diharapkan para cendikiawan hukum tidak bersikap arogan dan apriori, bahwa disiplin ilmu yang dimilikinya lebih tinggi 
dengan disiplin ilmu lainnya.

Kemudian filsafat hukum dengan

sifat universalitasnya memandang kehidupan secara menyeluruh, tidak memandang hanya bagian-bagian dan gejala kehidupan saja atau secara partikular. Dengan demikian filsafat hukum dapat menukik pada persoalan lain yang relevan atau menerawang pada keseluruhan dalam perjalanan refelektifnya, tidak sekedar hanya memecahkan masalah-masalah yang dihadapinya;

2. Bersifat mendasar atau memusatkan diri pada pertanyaan-pertanyaan mendasar (basic of fundamental questions). Artinya dalam menganalisis suatu masalah seseorang diajak untuk berpikir secara kritis dan radikal. Dengan mempelajari dan memahami filsafat hukum berarti diajak untuk memahami hukum tidak dalam arti hukum positif belaka. Orang yang mempelajari hukum dalam arti positif belaka, tidak akan mampu memanfaatkan dan mengembangkan hukum secara baik. Apabila orang itu menjadi hakim misalnya, dikhawatirkan ia akan menjadi hakim yang bertindak selaku 'corong undang-undang' semata;

3. Bersifat spekulatif. Sifat ini mengajak mereka yang mempelajari filsafat hukum untuk berpikir inovatif, selalu mencari sesuatu yang baru. Salah satu ciri orang yang berpikir radikal adalah senang kepada hal-hal yang baru. Tindakan spekulatif yang dimaksud adalah tindakan yang terarah, yang dapat dipertanggungjawabkan secara ilmiah. Dengan berpikir spekulatif dalam arti positif itulah hukum dapat dikembangkan kea rah yang dicita-citakan bersama;

4. Bersifat reflektif kritis. Melalui sifat ini filsafat hukum berguna untuk membimbing kita menganalisis masalah-masalah hukum secara rasional dan kemudian mempertanyakan jawaban itu secara terus-menerus. Secara kritis filsafat hukum berusaha untuk memeriksa gagasan-gagasan tentang hukum yang sudah ada, melihat koherensi, korespondensi, dan fungsinya. Filsafat hukum berusaha untuk memeriksa nilai dan pernyataanpernyataan yang dapat dikategorikan sebagai hukum;

5. Bersifat introspektif atau mempergunakan daya upaya introspektif. Artinya filsafat tidak hanya menjangkau kedalaman dan keluasan dari permasalahan yang dihadapi, tetapi juga mempertanyakan peranan dari dirinya dan dari permasalahan 
tersebut. Filsafat mempertanyakan tentang struktur yang ada dalam dirinya dan permasalahan yang dihadapinya. Sifat introspektif dan filsafat sesuai dengan sifat manusia yang memiliki hakikat dapat mengambil jarak tidak hanya pada hal-hal yang berada di luarnya tetapi juga pada dirinya sendiri". ${ }^{2}$

Kehadiran filsafat hukum memiliki arti dan peran besar bagi eksistensi dan pengembangan ilmuilmu pengetahuan hukum termasuk ilmu hukum dalam masa-masa dulu hingga sekarang di berbagai negara. Demikian pula halnya di Indonesia. Indonesia merupakan negara hukum (recht staat), dan bukan merupakan negara kekuasaan (macht staat). Hal tersebut ditegaskan berdasarkan ketentuan Pasal 1 ayat (3) UndangUndang Dasar Negara Republik Indonesia Tahun 1945 (UUD 1945), yang menentukan bahwa: "Negara Indonesia adalah negara hukum". 3

Indonesia memiliki kepribadian bangsa. Kepribadian dapat diartikan sebagai sifat hakiki yang tercermin pada sikap seseorang atau suatu bangsa yang membedakannya dari orang atau bangsa lain. Bangsa dapat diartikan sebagai masyarakat yang bersamaan

2 Teguh Prasetyo, dan Abdul Halim Barkatullah, Ibid, Halaman 4-6.

${ }^{3}$ Pada Pasal 3 ayat (1) Undang-undang Nomor 12 Tahun 2011 tentang Pembentukan Peraturan asal keturunan, adat, bahasa, dan sejarahnya, serta berpemerintahan sendiri. Berdasarkan pemaparan mengenai arti kepribadian dan arti bangsa, dapat ditegaskan bahwa kepribadian bangsa adalah ciri-ciri watak menonjol yang ada pada banyak warga suatu kesatuan nasional.

Telah dipaparkan sebelumnya bahwa kehadiran filsafat hukum memiliki arti dan peran besar bagi eksistensi dan pengembangan ilmuilmu pengetahuan hukum termasuk ilmu hukum dalam masa-masa dulu hingga sekarang di Indonesia. Pemikiran filsafat hukum di Indonesia masih dominan dipengaruhi filsafat hukum dari negara-negara asing. Dengan adanya kepribadian bangsa Indonesia yang notabene membedakan Indonesia dengan bangsa lainnya, tentunya para cendikiawan hukum perlu melakukan pemikiran filsafat hukum yang mengarah kepada kepribadian bangsa.

\section{Berdasarkan} berbagai pemaparan yang telah ada, timbul ketertarikan untuk meneliti guna mengetahui lebih lanjut mengenai pemikiran filsafat hukum yang mengarah kepada kepribadian bangsa, yang dibuat dalam suatu penulisan

Perundang-undangan (UU PPPU), ditentukan bahwa: "Undang-Undang Dasar Negara Republik Indonesia Tahun 1945 merupakan hukum dasar dalam peraturan perundang-undangan".

Jurnal Ilmiah "Advokasi" Vol. 06. No. 01 Maret 2018 
Karya Ilmiah berbentuk Makalah, dengan judul: "PEMIKIRAN

\section{FILSAFAT HUKUM KE ARAH KEPRIBADIAN BANGSA".}

\subsection{Permasalahan}

Adapun yang menjadi permasalahan dalam Makalah ini, sebagai berikut:

1. Bagaimana pemikiran filsafat hukum yang mengarah kepada kepribadian bangsa?

2. Bagaimana solusi agar pemikiran filsafat hukum para cendikiawan hukum di Indonesia mengarah kepada kepribadian bangsa?

\section{PEMBAHASAN}

2.1 Pemikiran Filsafat Hukum yang Mengarah Kepada Kepribadian Bangsa

Kehadiran filsafat hukum memiliki arti dan peran besar bagi eksistensi dan pengembangan ilmuilmu pengetahuan hukum termasuk ilmu hukum dalam masa-masa dulu hingga sekarang di berbagai negara. Demikian pula halnya di Indonesia. Hal ini adalah lumrah adanya karena filsafat pada umumnya merupakan induk pokok dari semua ilmu pengetahuan yang ada dan dikenal umat manusia hingga saat ini. Ketika ilmu pengetahuan hukum berakhir karena tidak mampu memberi jawaban yang memuaskan, maka pada saat itulah filsafat tampil sebagai dewa penolong. Hal ini terutama karena filsafat hukum juga mempelajari pertanyaan-pertanyaan yang tidak terjawab oleh ilmu hukum.

Para filsuf hukum senantiasa mempertanyakan pertanyaanpertanyaan yang pada hakikatnya adalah pertanyaan yang terpenting atau pokoknya saja yang berkenaan dengan masalah hukum sampai pada akarakarnya. ${ }^{4}$ Pemikiran filsafat hukum dilakukan sampai mencapai batas marginal atau sampai pada batas kemampuan pemikiran manusia yang terletak pada batas antara lingkungan empiris dan lingkungan metafisika, oleh karena itu sifat kedalaman dari pengertian filsafat hukum adalah sampai pada tindakan yang paling mendasar dan sekaligus bersifat kritis, tidak dogmatis dan tidak skeptis.

Soerjono Koesoemo Sisworo, menentukan bahwa:

"Filsafat hukum adalah (hasil) pemikiran yang metodis sistematis dan radikal mengenai hakikat dan hal-hal fundamental dan marginal dari hukum dalam segala aspeknya, yang peninjauannya berpusat pada 4 (empat) masalah pokok, yaitu:

1. Hakikat pengertian hukum;

2. Cita dan tujuan hukum;

3. Berlakunya hukum; 
4. Pengalaman/pengamalan hukum".5

Radikal tidak berarti sekedar mendalam sampai ke akar-akarnya, tapi sekaligus dalam arti kritis, tidak dogmatis, dan tidak skeptis. Marginal dimaksudkan sebagai sifat hakikat permasalahan pembatasan yaitu antara wilayah dan lahan empiris (pengalaman) dan metaempiris/metafisika. Keduanya didudukkan di atas landasan kesadaran, bahwa akal budi manusia walaupun dapat mengenai dan mengidentifikasi hakikat kebenaran, namun ia tidak mampu mengenali benda dalam dirinya sendiri (das ding an sich) yang ada di belakang dan menjadi hakikat terakhir dari segala kebendaan.

Teguh Prasetyo, dan Abdul Halim Barkatullah, menentukan bahwa:

"Filsafat hukum mengandung pula aspek dan momentum pandangan hidup dan dunia. Ini berarti filsafat hukum mengandung pula makna praktis dan penerapan, tidak berhenti pada perenungan teoritis abstrak tentang hakikat, kebenaran dan kearifan, baik yang transendental kritis logis maupun yang transendental fenomenologis, tapi sekaligus mengandung karsa dan dorongan semangat menghadapi, menanggulangi, dan mencari jalan keluar dari tantangan dalam kehidupan". 6

${ }^{5}$ Soerjono Koesoemo Sisworo, Mempertimbangkan Beberapa Pokok Pikiran Berbagai Aliran Filsafat Hukum Dalam Relasi dan Relevansinya Dengan Pembangunan/Pembinaan Hukum Indonesia, Pidato Pengukuhan Guru Besar, 1989, Halaman 3.

6 Teguh Prasetyo, dan Abdul Halim Barkatullah,
Teguh Prasetyo, dan Abdul Halim

Barkatullah, menentukan pula bahwa:

"Filsafat hukum memiliki komposisi dasar atau dua tiang penyangga pokok, yakni pada satu pihak filsafat difokuskan pada masalah kedudukan dan peranan manusia dalam dunia ini dan pada pihak lain berpijak pada ilmu dan ajaran politik, yaitu tentang bagaimana menyusun bangunan kehidupan bermasyarakat dan bernegara sebaik-baiknya. Komposisi dasar tersebut berkaitan pula dengan kodrat manusia dan kodrat alam dan benda/keadaan, yang masing-masing merupakan tempat sumber bahanbahan idiil hukum dan bahan-bahan hukum riil/materiil"? ?

Mengenai pengertian "filsafat hukum" Purnadi Purbacaraka dan Soerjono Soekanto, menentukan bahwa:

"Filsafat hukum adalah perenungan dan perumusan nilai-nilai kecuali itu filsafat hukum juga mencakup penyerasian nilai-nilai misalnya: penyerasian antara ketertiban dengan ketenteraman, antara kebendaan dengan keakhlakan, dan antara kelanggengan/konservatisme dengan pembaharuan". 8

Mahadi, menentukan bahwa:

"Filsafat hukum ialah filsafat tentang hukum falsafah tentang segala sesuatu dibidang hukum secara mendalam sampai ke akar-akarnya secara sistematis". 9 
Soedjono Dirdjosisworo, menentukan

bahwa:

"Filsafat hukum adalah pendirian atau penghayatan kefilsafatan yang dianut orang atau masyarakat atau negara tentang hakikat ciri-ciri landasan berlakunya hukum". ${ }^{10}$

Satjipto Rahardjo, menguraikan

filsafat hukum, sebagai berikut:

"Filsafat hukum mempersoalkan pertanyaan-pertanyaan yang bersifat dasar dari hukum. Pertanyaanpertanyaan tentang hakikat hukum tentang dasar-dasar bagi kekuatan mengikat dari hukum merupakan contoh-contoh pertanyaan yang bersifat mendasar itu. Atas dasar yang demikian itu, filsafat hukum bisa dihadapkan kepada ilmu hukum positif. Sekalipun sama-sama menggarap bahan hukum, tetapi masing-masing mengambil sudut pemahaman yang berbeda sama sekali. Ilmu hukum positif hanya berurusan dengan suatu tata hukum tertentu dan mempertanyakan konsistensi logis dari asas-asas, peraturan-peraturan, bidangbidang serta sistem hukumnya sendiri". 11

\section{Telah ditegaskan bahwa} Indonesia adalah negara hukum. Sebagai negara hukum, Indonesia memiliki kepribadian bangsa. Kepribadian dapat diartikan sebagai sifat hakiki yang tercermin pada sikap seseorang atau suatu bangsa yang membedakannya dari orang atau bangsa lain. Bangsa dapat diartikan sebagai masyarakat yang bersamaan asal keturunan, adat, bahasa, dan sejarahnya, serta berpemerintahan sendiri. Ditegaskan bahwa kepribadian bangsa adalah ciri-ciri watak menonjol yang ada pada banyak warga suatu kesatuan nasional.

Di Indonesia, sesuai dengan ketentuan Pasal 2 UU PPPU, Pancasila sebagai sumber dari segala sumber hukum. Selain sebagai sumber dari segala sumber hukum, Pancasila juga sebagai kepribadian bangsa Indonesia. Pancasila sebagai kepribadian bangsa Indonesia adalah perwujudan dari nilai-nilai budaya bangsa Indonesia sendiri yang diyakini kebaikan dan kebenarannya.

Sebelum ditetapkannya Pancasila sebagai dasar yang sah, Indonesia memang sudah sejak dahulu menganut nilai-nilai budaya luhur yang telah tercipta ditengah-tengah masyarakat nenek moyang Indonesia. Pancasila digali dari budaya bangsa Indonesia sendiri yang sudah ada, tumbuh, dan berkembang berabad-abad lamanya.

Pancasila sebagai kepribadian bangsa, hanya dimiliki oleh bangsa Indonesia sejak keberadaanya sebagai sebuah bangsa. Pancasila merangkum nilai-nilai yang sama yang terkandung dalam adat-istiadat, kebudayaan, dan agama-agama yang ada di Indonesia. Dengan demikian, Pancasila sebagai kepribadian bangsa Indonesia juga 
mencerminkan jiwa sekaligus

pandangan hidup rakyat Indonesia.

Filsafat hukum memiliki arti dan peran besar bagi eksistensi dan pengembangan ilmu-ilmu pengetahuan hukum termasuk ilmu hukum dalam masa-masa dulu hingga sekarang di Indonesia. Pemikiran filsafat hukum di Indonesia masih dominan dipengaruhi filsafat hukum dari negara-negara asing. Dengan adanya Pancasila sebagai kepribadian bangsa Indonesia yang notabene membedakan Indonesia dengan bangsa lainnya, tentunya para cendikiawan hukum perlu melakukan pemikiran filsafat hukum yang mengarah kepada Pancasila sebagai kepribadian bangsa, yang notabene mencerminkan jiwa sekaligus pandangan hidup rakyat Indonesia.

\subsection{Solusi Agar Pemikiran Filsafat} Hukum Para Cendikiawan Hukum di Indonesia Mengarah Kepada Kepribadian Bangsa

Asal muasal kata "Pancasila" berasal dari bahasa Sansekerta, yakni "Panca" yang berati lima, dan "sila/syla" yang berarti batu, sendi, alas atau sebuah dasar. Dapat ditegaskan bahwa Pancasila memiliki makna sebuah dasar yang terdiri dari 5 (lima) unsur. Kelima unsur Pancasila tersebut membentuk satu kesatuan yang saling mengikat dan terkait satu sama lain sehingga menjadikan fungsi Pancasila sebagai suatu dasar negara yang utuh dan sempuna.

Kedudukan Pancasila sebagai dasar negara dan pandangan hidup bangsa merupakan cerminan dari budaya masyarakat yang menganut nilai-nilai luhur, bahkan sebelum terciptanya Pancasila itu sendiri. Pancasila lahir dari hasil pemikiranpemikian serta ide maupun gagasan dari budaya yang dimiliki bangsa Indonesia sejak jaman dahulu. Hal ini merupakan cerminan dari fungsi kebudayaan bagi masyarakat itu sendiri sebagai sebuah pemersatu. Nilai-nilai Pancasila sebagai ideologi terbuka memperlihatkan kepribadian bangsa Indonesia itu sendiri, yakni terbuka terhadap segala perubahan.

Kepribadian dapat diartikan sebagai sifat hakiki yang tercermin pada sikap seseorang atau suatu bangsa yang membedakannya dari orang atau bangsa lain. Bangsa dapat diartikan sebagai masyarakat yang bersamaan asal keturunan, adat, bahasa, dan sejarahnya, serta berpemerintahan sendiri. Ditegaskan bahwa kepribadian bangsa adalah ciri-ciri watak menonjol yang ada pada banyak warga suatu kesatuan nasional.

Dewan Perancang Nasional menyatakan bahwa kepribadian Indonesia adalah karakteristik yang dimiliki oleh bangsa Indonesia dan 
berbeda secara menyeluruh dengan kepribadian bangsa-bangsa yang lain. Hal tersebut merupakan refleksi dari perubahan dan perkembangan bangsa Indonesia dari masa ke masa. Perubahan yang dialami bangsa Indonesia dipengaruhi dengan segala hal yang terjadi dalam mayarakat, adat budaya, serta lingkungan dalam masyarakat itu sendiri.

Nilai-nilai Pancasila sebagai ideologi terbuka memiliki peranan penting dalam membentuk kepribadian bangsa Indonesia. Membuat karakteristik bangsa menjadi terbuka terhadap segala perubahan yang terjadi baik di dalam maupun di luar negeri. Terbuka dengan kebudayaan maupun warga asing yang masuk ke Indonesia, dengan tidak meninggalkan kebudayaan asli milik bangsa Indonesia sendiri.

Dalam hal berdemokrasi, Pancasila sebagai kepribadian bangsa sangat penting untuk menyelesaikan masalah dengan jalan musyawarah tanpa adanya kekerasan. Dari hal tersebut terlihat manfaat musyawarah yang merupakan dasar dalam berpendapat tanpa melakukan pelanggaran hak warga negara. Pancasila sendiri merupakan dasar negara yang berasal dari cerminan kehidupan masyarakatnya, jadi merupakan milik bangsa Indonesia seluruhnya, dan bukan merupakan milik seseorang maupun golongan tertentu.

Selain merupakan kepribadian bangsa yang notabene mencerminkan jiwa sekaligus pandangan hidup rakyat Indonesia, sesuai dengan ketentuan Pasal 2 UU PPPU, Pancasila juga sebagai sumber dari segala sumber hukum di Indonesia. Untuk itu, maka sudah seharusnya para cendikiawan hukum di Indonesia melakukan pemikiran filsafat hukum yang mengarah kepada Pancasila sebagai kepribadian bangsa.

Tidak dapat dipungkiri bahwa filsafat hukum memiliki arti dan peran besar bagi eksistensi dan pengembangan ilmu-ilmu pengetahuan hukum termasuk ilmu hukum dalam masa-masa dulu hingga sekarang di Indonesia. Dengan kedudukan Pancasila sebagai sumber dari segala sumber hukum di Indonesia dan juga sebagai kepribadian bangsa, sudah seharusnya para cendikiawan hukum di Indonesia melakukan pemikiran filsafat hukum yang mengarah kepada Pancasila sebagai kepribadian bangsa. Fakta yang ada, pemikiran filsafat hukum para cendikiawan hukum di Indonesia masih dominan dipengaruhi filsafat hukum dari negara-negara asing, bukan dipengaruhi Pancasila sebagai filsafat negara. 
Pancasila merupakan filsafat negara yang lahir sebagai cita-cita bersama dari seluruh bangsa Indonesia. Hal tersebut ditegaskan karena Pancasila merupakan hasil perenungan jiwa yang mendalam, yang dilakukan oleh para pendiri bangsa Indonesia, yang kemudian dituangkan ke dalam suatu sistem (Pancasila sebagai sistem filsafat).

Pancasila sebagai sistem filsafat adalah suatu kesatuan yang saling berhubungan untuk satu tujuan tertentu dan saling berkualifikasi yang tidak terpisahkan satu dengan yang lainnya. Dapat ditegaskan bahwa Pancasila pada dasarnya satu bagian/unit-unit yang saling berkaitan satu sama lain dan memiliki fungsi serta tugas masing-masing.

Filsafat Pancasila memberikan pengetahuan dan pengertian ilmiah, yaitu tentang hakikat dari Pancasila. Sebagai filsafat, Pancasila memiliki karateristik sistem filsafat tersendiri yang berbeda dengan filsafat lainnya, diantaranya sila-sila Pancasila merupakan satu kesatuan sistem yang bulat dan utuh (sebagai suatu totalitas).

Sistem filsafat Pancasila mengandung citra tertinggi, yang terbukti dengan berbedanya sistem filsafat pancasila dengan sistem filsafat lainnya. Ciri khas perbedaan sistem filsafat Pancasila dengan sistem filsafat lainnya, sebagai berikut:

1. Sila-sila Pancasila merupakan satu kesatuan sistem yang bulat dan utuh (sebagai satu totalitas). Dengan pengertian lain bahwa apabila tidak bulat dan tidak utuh atau satu sila dengan sila yang lainnya terpisahpisah, maka bukanlah Pancasila;

2. Prinsip-prinsip filsafat Pancasila;

3. Susunan Pancasila dengan suatu sistem yang bulat dan utuh:

a. Sila 1, meliputi, mendasari, menjiwa sila 2 , sila 3 , sila 4 , dan sila 5;

b. Sila 2, diliputi, didasari, dan dijiwai sila 1 , serta mendasari dan menjiwai sila 3 , sila 4 , dan sila 5;

c. Sila 3, meliputi, mendasari, dan menjiwai sila 1 , sila 2 , serta mendasari jiwa sila 4, dan sila 5;

d. Sila 4, meliputi, didasari, dan dijiwai sila 1 , sila 2 , dan sila 3 , serta mendasari dan menjiwai sila 5 ;

e. Sila 5, meliputi, didasari, dan dijiwai sila 1 , sila 2 , sila 3 dan sila $4 .^{12}$

Apabila dikaji berdasarkan kausal Aristoteles, prinsip-prinsip sendiri. 
filsafat Pancasila dapat dijelaskan, sebagai berikut:

1. Kausa materialis, yakni sebab yang berhubungan dengan materi atau bahan. Dalam hal ini Pancasila digali dari nilai-nilai sosial budaya yang ada dalam bangsa Indonesia sendiri;

2. Kausa formais, yakni sebab yang berhubungan dengan bentuknya. Pancasila yang ada dalam Pembukaan UUD 1945 memenuhi syarat formal (kebenaran formal);

3. Kausa efisiensi. Hal ini dapat ditegaskan dengan adanya kegiatan Badan Penyelidik Usaha Persiapan Kemerdekaan Indonesia (BPUPKI) dan Panitia Persiapan Kemerdekaan Indonesia (PPKI) dalam menyusun dan merumuskan Pancasila menjadi dasar negara;

4. Kausa finalis, yakni berhubungan dengan tujuan, yaitu tujuan diusulkannya Pancasila sebagai dasar negara. Adapun inti atau esensi sila-sila Pancasila, sebagai berikut:

a. Tuhan, yaitu sebagai kausa prima;

b. Manusia, yaitu mahluk individu dan mahluk sosial;

c. Satu, yaitu kesatuan yang memiliki kepribadian sendiri; d. Rakyat, yaitu unsur mutlak negara, harus bekerja sama dan bergotong-royong;

e. Adil, yaitu memberikan keadilan pada diri sendiri dan orang lain.

Pancasila sebagai sistem filsafat memiliki beberapa nilai, yaitu nilai objektif dan juga nilai subjektif. Nilai objektif sistem filsafat Pancasila, sebagai berikut:

1. Rumusan dari sila-sila Pancasila menunjukkan adanya sifat-sifat yang umum, universal, dan abstrak. Pada hakikatnya Pancasila adalah nilai;

2. Inti nilai-nilai Pancasila berlaku tidak terikat oleh ruang. Artinya keberlakuannya sejak jaman dahulu, masa kini dan juga untuk masa yang akan datang, untuk bangsa Indonesia boleh jadi untuk negara lain yang secara eksplisit tampak dalam adat-istiadat, kebudayaan, tata hidup kenegaraaan, dan tata hidup beragama;

3. Pancasila yang terkandung dalam Pembukaan UUD 1945 memenuhi syarat sebagai pokok kaidah negara yang fundamental, sehingga merupakan suatu sumber hukum positif di Indonesia. Untuk itu maka hierarki suatu tertib hukum di Indonesia berkedudukan sebagai tertib hukum tertinggi. Maka secara objektif tidak dapat diubah secara 
hukum, sehingga melekat pada

kelangsungan hidup negara. Sebagai

konsekuensinya, jikalau nilai-nilai

yang terkandung dalam pembukaan

UUD 1945 itu diubah, maka sama halnya dengan membubarkan Indonesia.

Adapun nilai subjektif sistem filsafat Pancasila, sebagai berikut:

1. Nilai Pancasila timbul dari bangsa Indonesia itu sendiri. Nilai-nilai yang terdapat dalam Pancasila merupakan hasil dari pemikiran, penilaian, dan refleksi filosofis dari bangsa Indonesia sendiri. Ideologi Pancasila berbeda dengan ideologi lainnya. Hal tersebut ditegaskan karena isi Pancasila diambil dari nilai budaya bangsa dan religi yang telah melekat erat, sehingga jiwa Pancasila adalah jiwa bangsa Indonesia sendiri, sedangkan ideologi lain seperti liberalis, sosialis, komunis, dan lain sebagainya merupakan hasil dari pemikiran filsafat orang;

2. Nilai Pancasila merupakan filsafat bangsa Indonesia. Pancasila sebagai pandangan hidup bangsa Indonesia menjadi pedoman bangsa untuk mengatur aspek kehidupan berbangsa dan bernegara sekaligus menjadi cermin jati diri bangsa yang diyakini sebagai sumber nilai atas kebenaran, keadilan, kebaikan, dan kebijaksanaan dalam kehidupan bermasyarakat, berbangsa, dan bernegara;

3. Pancasila merupakan nilai-nilai yang sesuai dengan hati nurani bangsa Indonesia, karena bersumber dari kepribadian bangsa. Sehingga dalam perjalanannya akan selaras dengan nilai-nilai Pancasila.

Telah ditegaskan sebelumnya bahwa sesuai dengan ketentuan Pasal 2 UU PPPU, Pancasila merupakan sumber dari segala sumber hukum di Indonesia. Untuk itu maka dalam kehidupan bernegara, nilai dasar Pancasila harus tampak dalam produk peraturan perundang-undangan yang berlaku. Dapat ditegaskan bahwa seluruh peraturan perundang-undangan yang ada di Indonesia harus dijiwai nilai-nilai Pancasila, sehingga tidak boleh bertentangan dengan nilai-nilai Pancasila. Oleh karena itu pula maka sudah sepantasnya apabila para cendikiawan hukum di Indonesia melakukan pemikiran filsafat hukum ke arah Pancasila yang merupakan kepribadian bangsa.

Telah dipaparkan sebelumnya bahwa merupakan suatu fakta bahwa pemikiran filsafat hukum para cendikiawan hukum di Indonesia masih dominan dipengaruhi filsafat hukum dari negara-negara asing. Terhadap fakta tersebut, tentunya 
haruslah dapat ditemukan solusinya.

Adapun solusi agar pemikiran filsafat hukum para cendikiawan hukum di Indonesia mengarah kepada kepribadian bangsa adalah dengan cara menghimbau dan mengarahkan para cendikiawan hukum untuk berpegang teguh pada Pancasila sebagai kepribadian bangsa.

\section{PENUTUP}

\subsection{Simpulan}

Adapun yang menjadi simpulan dalam Makalah ini, adalah:

1. Pemikiran filsafat hukum yang mengarah kepada kepribadian bangsa adalah berupa pemikiran filsafat hukum yang mengarah kepada Pancasila sebagai kepribadian bangsa, yang notabene mencerminkan jiwa sekaligus pandangan hidup rakyat Indonesia.

2. Solusi agar pemikiran filsafat hukum para cendikiawan hukum di Indonesia mengarah kepada kepribadian bangsa adalah dengan cara menghimbau dan mengarahkan para cendikiawan hukum untuk berpegang teguh pada Pancasila sebagai kepribadian bangsa.

\subsection{Saran}

Adapun yang menjadi saran dalam karya ini, adalah: Agar Pemerintah mensosialisasikan himbauan guna mengarahkan para cendikiawan hukum di Indonesia untuk melakukan pemikiran filsafat hukum berdasarkan Pancasila sebagai kepribadian bangsa.

\section{DAFTAR PUSTAKA}

\section{A. Bahan Hukum Primer}

Undang-Undang Dasar Negara Republik Indonesia Tahun 1945.

Undang-undang Nomor 12 Tahun 2011 tentang Pembentukan Peraturan Perundang-undangan.

\section{B. Bahan Hukum Sekunder}

Apeldorn, Van, 1976. Pengantar Ilmu Hukum, Pradnya Paramitha, Jakarta,

Prasetyo, 2012. Teguh, dan Abdul Halim Barkatullah, Filsafat, Teori, dan Ilmu Hukum (Pemikiran Menuju Masyarakat yang Berkeadilan dan Bermartabat), Raja Grafindo Persada, Jakarta,

Rasjidi, Lili, 2004. Filsafat Hukum (Apakah Hukum Itu?), Remaja Karya, Bandung,

\section{Bahan Hukum Tertier}

Sisworo, Soerjono Koesoemo, 1989. Mempertimbangkan Beberapa Pokok Pikiran Berbagai Aliran Filsafat Hukum Dalam Relasi dan Relevansinya Dengan Pembangunan/Pembinaan Hukum Indonesia, Pidato Pengukuhan Guru Besar, 